\title{
The next big epidemic? Device shutdowns
}

\author{
Fiona Ecarnot ${ }^{1,2^{*}} \mathbb{D}$, Basile Mouhat ${ }^{1}$, Mathilde Giffard ${ }^{3}$, Martin Pillet ${ }^{3}$ and Marie-France Seronde ${ }^{1,2}$
}

C 2021 Springer-Verlag GmbH Germany, part of Springer Nature

Dear Editor,

Science fiction films in the 1980s and 1990s depicted futuristic characters communicating remotely through various sorts of earpieces, mouthpieces and transponders. Little did we think at the time that one day, almost every one of us would be carrying a miniaturized device in our pocket or bag, capable of giving us instant access to unlimited information, or letting us talk in real time to someone on the other side of the planet, while looking at a crystal clear image of them on the screen at the same time. On a par with the evolution of mobile phone technology, there has been outstanding progress over the last few decades in the care of heart failure. Foremost among the technological developments to assist failing hearts has been the invention of temporary and permanent mechanical cardiac support devices, such as the HeartMate $^{\mathrm{TM}}$, Thoratec ${ }^{\mathrm{TM}}$ left ventricular assist device (LVAD), the Jarvik 2000 LVAD, and the Berlin total artificial heart. Since their introduction, LVADs like the HeartMate $^{\mathrm{TM}}$ have provided support and prolonged life in many patients with advanced heart failure, either as a bridge to transplantation or as destination therapy. Assist devices or transplantation are indicated when all other medical therapeutic options have been exhausted. However, with the growing shortage of donors for transplantation, devices like the HeartMate ${ }^{\mathrm{TM}}$ are being increasingly used worldwide.

As Shakespeare's Hamlet would have said (Act III, Scene 1), therein lies the rub. The rate of use of LV assist devices in clinical practice has now outstripped the pace of the technology's continuing development, creating new dilemmas, which we now have to resolve. Take this recent case from our department as an example:

\footnotetext{
*Correspondence: Fiona.ecarnot@univ-fcomte.fr

1 Department of Cardiology, University Hospital Besancon, Boulevard Fleming, 25000 Besancon, France
}

Full author information is available at the end of the article our patient, let's call him Mr. Smith, was implanted with a HeartMate ${ }^{\text {TM }}$ device in 2015 as destination therapy for advanced heart failure. He also had an implantable cardioverter defibrillator since 2013 for primary prevention. He was followed regularly in our department, and built up a good rapport with our team. Over the years, he suffered repeated infections on his device, and had been on long-term antibiotic therapy for the last few years. In recent months, his overall condition had deteriorated considerably, but he was still autonomous, and living at home with his wife.

He was admitted again due to a malfunction of the device's controller. We found that the driveline was denuded, and was generating short circuits in the controller, with the result that alarms were ringing constantly on the device. Naturally, this situation was creating considerable anxiety and worry in the patient and his wife, besides being a major nuisance. Mr. Smith was admitted in the hope that we could find a solution to stop the alarms ringing. Unfortunately, his overall condition was too weak to enable replacement surgery. The short circuits would keep recurring, even if we had been able to change the controller, which was a first generation model and no longer widely available. There was a persistent risk that the device would malfunction definitively, and that Mr. Smith would die, so it seemed prudent to keep him in hospital while a solution was being found, but his dearest wish was to be discharged, so that he could die in his family home, like his parents and grandparents before him. Surprisingly, in the device's main menu, the physician can switch the whole device off (which would result in almost immediate death), but there is no possibility to mute the alarms. From a design point of view, it is understandable that the alarms serve an important purpose, but it seems illogical to be able to switch off the device completely (leading to certain death), but not the alarms (whose failure to alert may or may not lead to death). Surely we had not come to a point where we would have to switch off Mr. Smith's device and let him die, just to

\section{Springer}


mute the alarms? It should be noted here that Mr. Smith himself was not averse to that solution.

Here's where we get to the crux of the matter. The technological assistance provided to Mr. Smith to keep him alive was now preventing him from experiencing the endof-life that he wanted for himself. On the one hand, both Mr. Smith and his wife clearly stated that the 6 extra life years he gained with the HeartMate ${ }^{\mathrm{TM}}$ were the best years of their life. On the other hand, would he have accepted the device if he had known in what conditions his endof-life would play out? Perhaps not-other patients have refused.

From the physician's point of view, the same dilemma arises: when we propose ever more complex and technological solutions to patients who have exhausted every other option medicine has to offer, we must also consider the difficulties that lie down that path. With the perspective of these new situations, and difficult end-of-life choices, it is of paramount importance to discuss end-oflife wishes and values with patients as early as possible in the course of disease. The same is valid for patients in whom defibrillator implantation is being contemplated. At the end-of-life, the defibrillator may "rob" the patient of an opportunity to die in a manner that is in line with their wishes, so the issue of what to do with a defibrillator at the end-of-life needs to be addressed early on. We need to consider not only the initiation of life-prolonging therapy, but also how to bring it to an end in a manner that is consistent with the patient's end-of-life wishes. Maybe the next big pandemic will be an epidemic of shutdownsswitching off devices we previously implanted, to let our patients go.
Getting back to Mr. Smith-with a little bit of tweaking to the wires, we managed to find a solution whereby he could mute the alarms via the controller every $4 \mathrm{~h}$ when they started to ring. At least he was able to go home. Two days after discharge, he died quietly in his sleep, in his ancestral home, with his wife by his side.

Well, quietly enough... the alarms were still ringing.

\footnotetext{
Author details

${ }^{1}$ Department of Cardiology, University Hospital Besancon, Boulevard Fleming, 25000 Besancon, France. ${ }^{2}$ EA3920, University of Franche-Comté, 25000 Besancon, France. ${ }^{3}$ Mobile Palliative Care Team, University Hospital Besancon, 25000 Besancon, France.
}

\section{Acknowledgements}

The authors thank Jean-Pierre Quenot (INSERM, CIC 1432, Module Épidémiologie Clinique, Dijon, France - Équipe Lipness, Centre de Recherche INSERM UMR1231 Et LabEx LipSTIC Université de Bourgogne-Franche Comté, Dijon, France - Espace de Réflexion Éthique Bourgogne Franche-Comté (EREBFC), Dijon, France) and Nicolas Meneveau (Department of Cardiology, University Hospital Besancon, 25000 Besancon, France - EA3920, University of FrancheComté, 25000 Besancon, France) for their contribution to this manuscript.

Declarations

Conflicts of interest

No author has any conflict of interest to declare.

Informed consent

Consent for publication was obtained from the patient's family.

\section{Publisher's Note}

Springer Nature remains neutral with regard to jurisdictional claims in published maps and institutional affiliations.

Received: 1 October 2021 Accepted: 12 November 2021

Published online: 14 January 2022 